\title{
Reliability and performance analysis of a mini solar home system installed in Indonesian household
}

\author{
Prisma Megantoro, Hafidz Faqih Aldi Kusuma, Sinta Adisti Reina, Abdul Abror, Lilik Jamilatul \\ Awalin, Yusrizal Afif \\ Faculty of Advanced Technology and Multidiscipline, Universitas Airlangga, Surabaya, Indonesia
}

\begin{abstract}
Article Info
Article history:

Received Aug 25, 2021

Revised Jun 14, 2021

Accepted Dec 4, 2021

Keywords:

Electricity consumption

Photovoltaic

Reliable electricity

Renewable energy

ABSTRACT

During the COVID-19 pandemic since early 2020 in Indonesia, the demand for electrical energy in the housing sector has increased significantly. This is due to the government's recommendation to reduce activities on the outside and work from home, specifically for educational and entertainment activities. Those are almost recommended to be done online. Many people complain about the increase in monthly electricity payments compared to before the pandemic. The construction of solar power plants in housing/solar home systems (SHS) will reduce the electricity consumption from the public grid. This SHS installation can be used to supply some household electricity needs, such as computers, televisions, internet facilities, lighting, et cetera. In this article, the researchers discuss the performance testing of SHS with a capacity of $300 \mathrm{Wp}$. It is installed in the house buildings accompanied by the design and measurement of solar energy potential.
\end{abstract}

Solar home system

This is an open access article under the CC BY-SA license.

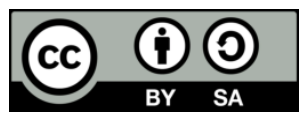

\section{Corresponding Author:}

Prisma Megantoro

Faculty of Advanced Technology and Multidiscipline, Universitas Airlangga

Surabaya, Indonesia

Email: prisma.megantoro@stmm.unair.ac.id

\section{INTRODUCTION}

Solar power generation systems have been applied to various locations that require a supply of electrical energy apart from the public electricity grid. In Indonesia, solar power plants mostly use photovoltaic technology. This technology uses silicon wafers to convert solar energy into electrical ones [1]-[6]. The application of solar power generation systems is very diverse, such as centralized generation, distributed generation, solar home system (SHS) [7]-[10], solar water pump system [11]-[14], public street lighting [15]-[17] and also solar-powered electric vehicles [18].

The SHS is usually used to reduce electrical energy consumption from the public grid with a smartgrid topology [19]. This application allows solar power generation systems to increase the availability of electricity for the users [20]. The demand for building SHS in the housing sector in Indonesia is also increasing. It is related to the government's policy of buying and selling electricity with the state electricity company (PLN). Apart from being a backup power source, this system is also useful for reducing electricity bills for the public grid. In designing this system, it is always necessary to use the right calculation method so that the solar power plant system built can operate optimally. The conducted calculations must also consider the topology of the installation location and the specifications of the solar power generation system.

Several studies related to the method of calculating the SHS design have been done. One of them is the research conducted by the researchers in designing a solar water pump system for the residential sector [21]. Another research was also conducted by Diantari and Pujotomo [22], in designing a solar power system with a capacity of $5 \mathrm{~kW}$. Furthermore, Khin et al. [23], estimated solar radiation and optimal tilt angle in a 
photovoltaic system in a college building. About the software, Paluch et al. [24], design a sizing tool for solar photovolatic system. Beside that, Bukvina et al. [25] has developed a software used to calculate the potential for solar radiation and based on location coordinates.

\section{RESEARCH METHOD}

The method of this study is to determine the performance of the SHS installed in the housing with an adjustable capacity. The SHS is designed to have an off-grid or stand-alone topology without a connection to the public electricity network. The electrical connection from SHS is only for certain electrical loads that are separate from the electrical ones, which are connected to the public electricity network.

The research method is shown in Figure 1(a) begins with the calculation of the potential for solar energy in Indonesia with a case study of Surabaya city. The solar energy potential data is secondary data obtained from RETScreen. The second stage is calculating the need for electrical energy per day for 24 hours, day and night. The third one is the calculation of the number and specifications of each system component. Finally, the last one measures the system performance based on the results of direct measurements in the field with an adjusting electrical load.

Figure 1(b) shows a block diagram of an SHS, consisting of the system's main components. Photovoltaic solar panels are generating units that are used to harvest solar energy into electrical ones. The solar charge controller (SCC) is used to optimize energy harvest from solar panels with the maximum power point tracking (MPPT) feature. Part of the storage unit used a VRLA battery. Inverters are used to convert direct current (DC) electricity into alternating current (AC) electricity. Hence, they can be used to supply electrical loads. As an additional component, SHS also has a pair of miniature circuit breakers (MCB) mounted on both the DC and AC sides. In addition, there are monitoring devices and dataloggers for monitoring system parameters.

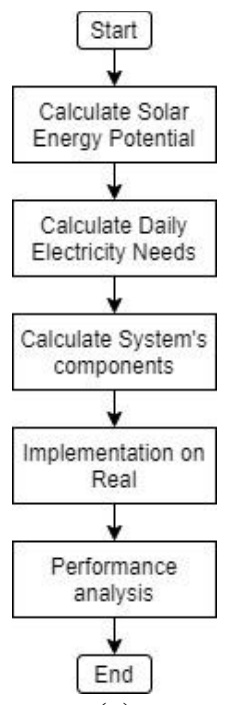

(a)

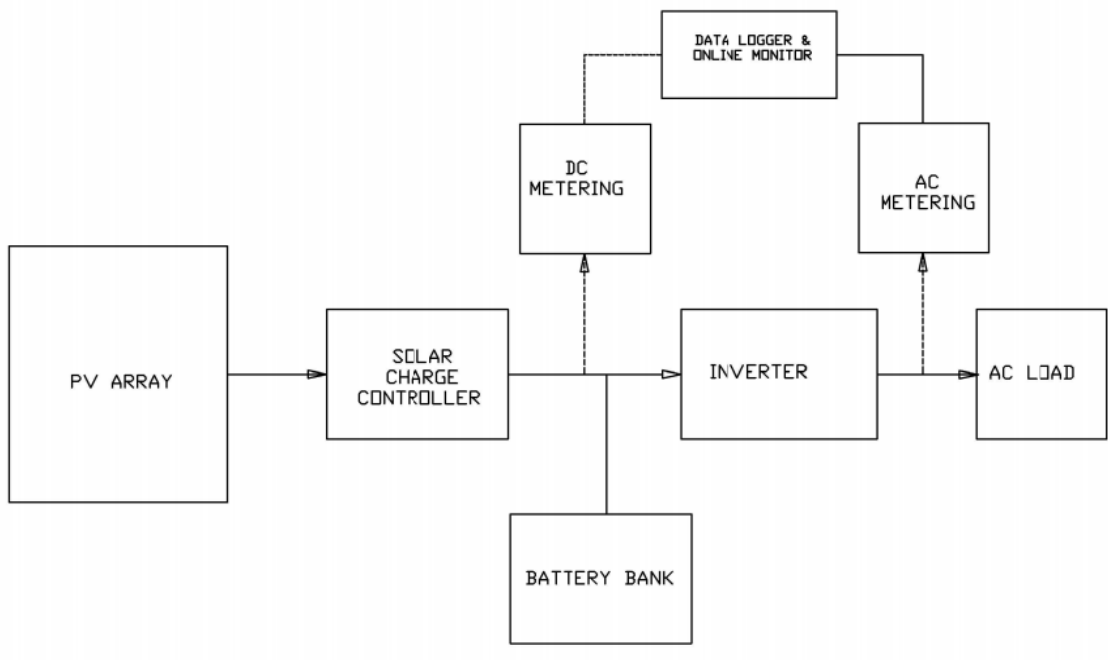

(b)

Figure 1. Design of research method (a) SHS design workflow and (b) SHS block diagram

\subsection{Solar energy potential}

Surabaya is located at the coordinates of $07^{\circ} 09^{\prime} 00^{\prime \prime}-07^{\circ} 21^{\prime} 00^{\prime \prime}$ south latitude and $112^{\circ} 36^{\prime}-112^{\circ} 54^{\prime}$ east longitude. In this study, the value of direct normal insolation (DNI) was obtained by direct measurement in the field using a solar power meter. The determination of DNI is the lowest solar insolation value during peak sun hours (PSH). The PSH is a parameter to express the ratio of the maximum solar radiation duration (in hours) per day to the standard solar radiation intensity, which is $1 \mathrm{~kW} / \mathrm{m}^{2}$. The PSH start from the time when the intensity is raising to more than $60 \%$ of the highest intensity and ends when the intensity is lower than $60 \%$ of the highest intensity of that day. According to [26], the value of PSH in Indonesia is 4-5 hours. In this study, the determination of the PSH value is seen from the insolation graph resulting from the measurement of the sunlight power. PSH starts and ends when the solar insolation reaches a point above $60 \%$ or about $600 \mathrm{~W} / \mathrm{m}^{2}$.

By taking the minimum value of DNI, it is hoped that the SHS system can work optimally even in the worst conditions. Furthermore, the analysis of the demand for electrical energy harvested by the solar panels 
is obtained from the amount of energy consumed by the load every day. Therefore, the DNI value can be used as a reference for the estimated output power generated by the solar panels in the array when installed on-site.

\subsection{Daily electricity needs}

The total need for electrical energy used in several buildings in a day can be calculated by (1).

$$
E_{\text {total }}=\sum n x t
$$

where $E_{\text {total }}$ of the electrical energy total amount needed for each electrical device per day, $n$ is the number of each electrical device that has been used per day. $t$ is the time of use of each device per day.

\subsection{System specification}

The first thing calculated from the SHS component is the number and specifications of the solar panels. This calculation involves the PSH value. Then, with the total electrical energy consumption that has been calculated, the total capacity required for $P_{-}$pv array PV panels can be calculated in (2).

$$
P_{\text {pv_com }}=\frac{E_{\text {total }}}{\text { PSH } x P_{\text {minimum_DNI }}}
$$

With the solar panel capacity expressed in $P_{p v_{-} c o m}$, it will be possible to design series and parallel connection configurations in the solar panel array. The number and type of connections are used as a reference to determine the operating voltage and current in the generating unit. Afterward, the SHS design also considers the electrical losses that occur in each component of the system, which in this study is $6.5 \%$. By considering the formula, the calculation in (3).

$$
P_{p v_{-} \text {total }}=\frac{P_{p v_{-} \text {com }}}{\left(100 \%-\text { Loss }_{\text {Total }} \%\right)}
$$

The configuration of the solar panel array is expressed by the number of series and parallel connections. Each parallel connection $\left(n_{p}\right)$ will double the current. Meanwhile, the series connection $\left(n_{s}\right)$ will double the voltage.

$$
n_{s_{-} p v}=\frac{V_{\text {system }}}{V_{m p}}
$$

where $V_{\text {system }}$ is the operating voltage. On the other hand, $V_{m p}$ is the maximum voltage of the solar panel array.

$$
n_{p_{-} p v}=\frac{P_{p v_{-} t o t a l}}{P_{p v}}
$$

where $P_{p v}$ is the maximum electric power of the solar panel array.

This SHS is activated to meet the electricity needs for 24 hours. Therefore, a storage unit is needed. It uses a battery array to store the electrical energy generated by the generating unit. The storage unit capacity considers the total energy generated by the generating unit during PSH and the hourly load power. The energy that the battery must store is described in (6).

$$
W_{\text {battery }}=P_{\text {pv_com }} \times P S H
$$

where $W_{\text {battery }}$ is the capacity of the storage system stated in the energy $(\mathrm{Wh} / \mathrm{kWh})$.

Moreover, this energy is the product of the battery voltage $\left(V_{\text {battery }}\right)$ ), which is stated in volts multiplied by the current capacity of the battery. The solar power generation system is indeed suitable for using VRLA type batteries, both dry and gel with a deep discharge ( $D o D) 80 \%$. The current capacity of the battery is described in (7).

$$
I_{\text {bat_total }}=\frac{W_{\text {battery }}}{V_{\text {system }} \times D o D}
$$

SCC has a maximum power point tracking (MPPT) feature, in which this feature serves to track the maximum power point voltage of the solar panel array $\left(V_{m p p}\right)$. The DC/DC converter on the SCC will convert 
the charging voltage into a $V_{m p p}$ Voltage. This will increase the production of electrical energy and the efficiency of the system. This MPPT feature usually uses certain programming algorithms to conduct its functions, such as genetic algorithms [27]-[30]. The calculation of the capacity and specifications of the SCC considers the system voltage and the specifications of the solar panels used. Therefore, the calculation of voltage and current specifications must be met according to (8) and (9).

$$
V_{s c c}=n_{p} x V_{o c}
$$

where; $V_{s c c}$ is the SCC voltage. Meanwhile, $n_{p}$ is the number of solar panels connected in parallel. As for the $V_{o c}$, it is the open-circuit voltage.

$$
I_{s c c}=I_{s c} \times n_{s} \times 1.5
$$

$I_{s c c}$ is the current required SCC capacity and $n_{s}$ is the number of PV panels connected in series. Moreover, the current capacity of the SCC must be multiplied by 1.5 to compensate for $50 \%$. This $50 \%$ compensation is required to prevent overcurrent from the solar panel array.

Determination of inverter capacity in solar power plants only considers the total power used by all loads plus $25 \%$ compensation. This is considered to avoid overload or "in-rush" current generated by inductive electrical loads. The inverter capacity is calculated by (10).

$$
P_{\text {inverter }}=\left(\sum V_{\text {load }} \times I_{\text {load }}\right) \times 1.25
$$

where $V_{\text {load }}$ is the voltage of each electrical load, which is about $220 \mathrm{~V}$. Meanwhile, $I_{\text {load }}$ is the RMS current of each electrical load.

\subsection{System performance}

SHS is built with a design following the calculation of energy potential, electricity demand, and component specifications. Before being fully operational, it is necessary to test the reliability of the system. This is conducted to determine that the SHS can harvest enough energy to supply electricity to the load. At the same time, it reveals that SHS can store electrical energy appropriately and not excessive or lacking. This analysis was conducted by measuring for a full 24 hours. The parameters observed are from the generation unit to the distribution one. From the generation unit, there is a solar panel current and voltage. Afterward, the battery current and voltage are controlled by the SCC. The output power of the SCC will determine the quality level of the power harvest from the solar panels. In addition, from the AC side, current, voltage, power, frequency, and energy are the outputs of the inverter. The output of this inverter will determine the quality of the electrical energy supply to the load.

\section{IMPLEMENTATION}

The SHS design calculation method is applied to its construction with a capacity of $300 \mathrm{Wp}$. This SHS is used to supply household entertainment devices: wifi router, tv box, and LED tv. SHS is operated for 24 hours with non-stop loading.

Figure 2(a) shows a graph of the solar insolation on a daily cycle from 05.00 to 18.00 . This graph is used to determine the PSH and the maximum and minimum solar insolation points. If this SHS is used to power the wifi router and tv box with a power of $5.5 \mathrm{~W}$-that is turned on for 24 hours per day- as well as a $27 \mathrm{~W}$ LED television-that is turned on for 12 hours per day-then the total power that must be met is 456 Wh per day with a PSH value of 3.5 hours. That is during 10.00-13.00. Calculated in (2), the power value $\left(P_{p v_{-} c o m}\right)$ is 200 $\mathrm{Wp}$. If the value of losses is entered into (3), then the total capacity of the solar panel array required is $308 \mathrm{Wp}$ and rounded up to $300 \mathrm{Wp}$. According to the standard, a solar power plant with a capacity below $1 \mathrm{kWp}$ must have an operating voltage $\left(V_{\text {system }}\right)$ of $12 \mathrm{~V}$. Therefore, the arrangement of the PV panels is configured into three series to meet the minimum input voltage requirements for SCC. The same data described in the previous subchapter were taken using a Lutron brand solar power meter with SPM 116SD type. As shown in Figure 2(b), the solar insolation measurements are carried out near the solar panel installation on the roof of the house/building. 


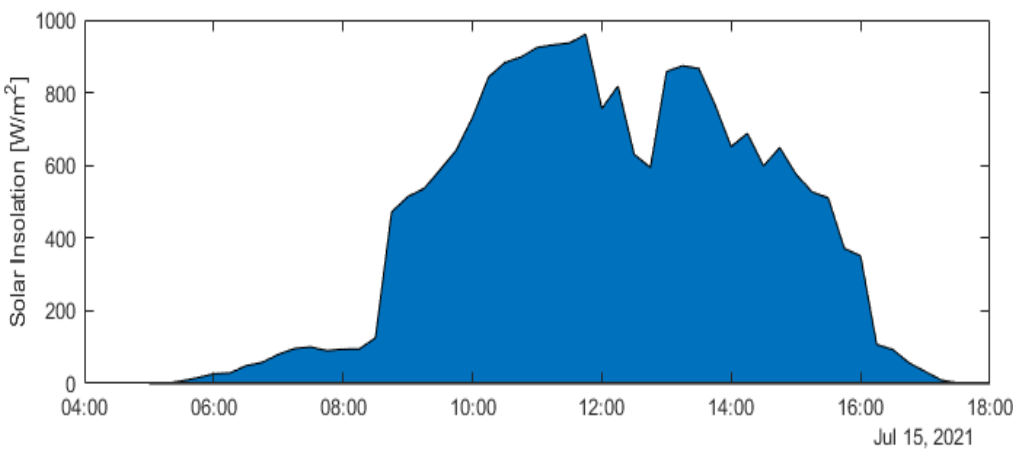

(a)

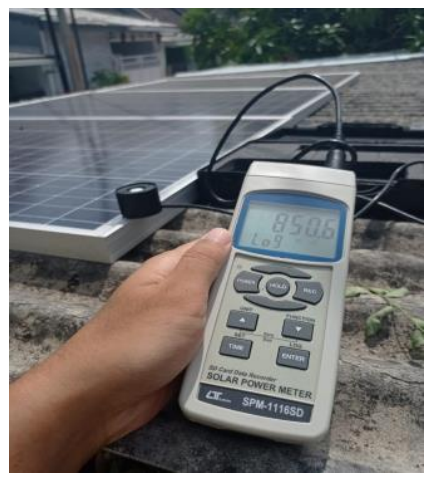

(b)

Figure 2. Solar insulation measurement (a) solar insolation occurred in location and (b) data collection process

The calculation of the number and specifications of the battery can be seen from the stored electrical energy. Furthermore, based on (6), the electrical energy that must be stored by the battery $\left(W_{\text {battery }}\right)$ is 700 Wh. In addition, the value of I_( $\left.I_{\text {bat_total }}\right)$ in this SHS is $58.33 \mathrm{Ah}$. Therefore, it is rounded up according to the battery stock on the market to $55 \mathrm{Ah}$.

The calculation of SCC specifications is seen from the specifications, configuration, and the number of the used PV panels. Based on (8), with $V_{o c}$ on the solar panel is $21.24 \mathrm{~V}$, a minimum voltage specification of $63.72 \mathrm{~V}$ is required. As shown in (7), with the $I_{s c}$ value on the PV panel of $6.22 \mathrm{~A}$, a minimum current specification of $6.22 \mathrm{~A}$ is required.

The calculation of inverter specifications is only considered from the total electrical load power. In this study, the total load power for the wifi router, tv box, and LED tv is $34 \mathrm{~W}$. Coupled with a power compensation of $25 \%$, it is safe for SHS to use an inverter with a power not less than $42.5 \mathrm{~W}$. Because SHS has an operational voltage $12 \mathrm{~V}$, the inverter must also have an input voltage specification of $12 \mathrm{~V}$.

\section{RESULTS AND ANALYSIS}

\subsection{SHS installation}

The results of the calculation implementation of each SHS component are contained in this section, along with the detailed engineering design (DED) for each SHS configuration. The design uses a solar panel with a P_pv of $100 \mathrm{Wp}$. Based on (4) and (5); hence, three series configurations are required. The number of solar panels needed is three units. The cable used in the PV panel array uses the NYYHY type with $2 \times 1.5 \mathrm{~mm}$ square size. The choice of this type of cable is suitable for use in outdoor areas and is more resistant to air and weather. The size of the cable is, of course, adjusted to the current from the solar panel. Based on the calculation results of the storage unit, only 1 unit of 12 V 55 Ah VRLA type battery with a DoD level of $80 \%$ is needed.

Figure 3 shows the SHS design with a single line diagram based on the following design, and the cable specifications and configuration of all system components. It is added with the metering from the DC and AC sides. Wiring on the DC side control panel uses the NYAF type with a size of $5 \mathrm{~mm}$ square. Meanwhile, the AC side uses the NYH type with a square size of $1.5 \mathrm{~mm}$ square. The cable type shown in Figure 4 follows the standard of use. In comparison, the size is adjusted to the voltage and electric current that passes.

Figure 4 shows a $300 \mathrm{Wp}$ mini SHS installation on site. Another important thing is the PV panel array installation and controller panel placement by considering the topology above the house. The elevation angle of the PV panels is 10-15 degrees, which faces the equator. Therfore, if the location is south of the equator, the PV panels must face north and vice versa. In addition, there should be no objects from the east, west, and north that have a height higher than the PV panel installation. This can cause shadows on the surface of the PV panel array.

Afterward, the panel distance between the array to the controller and the battery panels should not be more than 50 meters. This will cause huge losses on the DC side. In this study, the distance from the solar panel array to the controller panel is 13.5 meters. Moreover, the mini SHS installation at the site already meets the standards mentioned. 
PANEL CINTRDLLER \& BATTERY

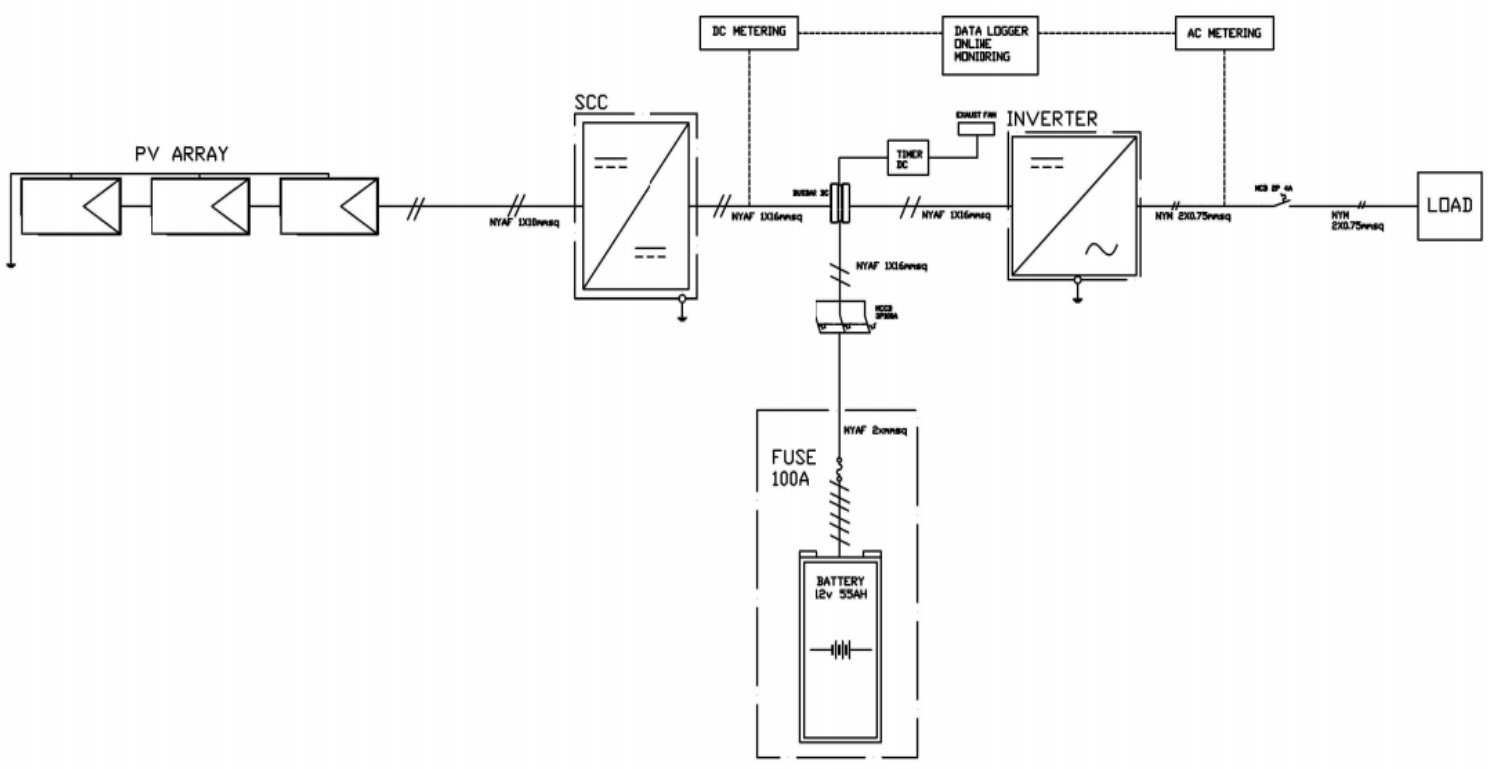

Figure 3. Single line diagram of mini SHS

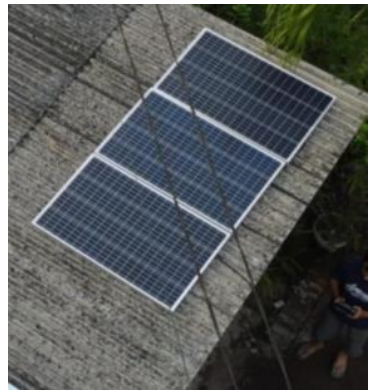

(a)

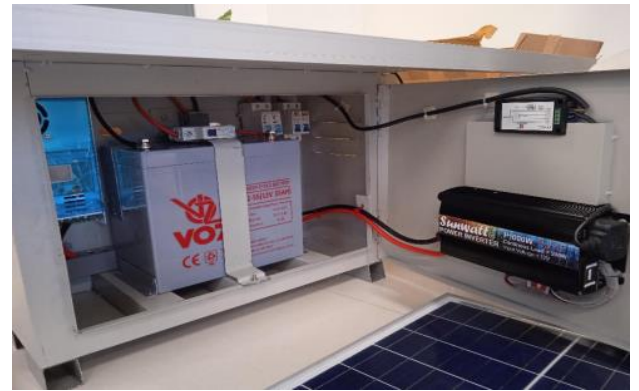

(b)

Figure 4. $300 \mathrm{Wp}$ mini SHS installation in the rooftop (a) PV panel array and (b) controller and battery panel box

\subsection{SHS performance analysis}

The performance analysis of the mini SHS that has been built is conducted to determine the level of system reliability. This test aims to determine that the mini SHS system can harvest enough solar energy and supply electricity for several electronic devices in the household. The data collection was conducted on July 15,2021 , for 24 hours, especially for solar insolation data, which was only from 05.00 to 18.00 . It follows the daily cycle of the sun.

Figure 5 shows that the solar energy available for 13 hours of irradiation on July 15, 2021, is 14.8 $\mathrm{kWh}$. Meanwhile, the electrical energy produced is $4.2 \mathrm{kWh}$. Thus, the energy harvested into electrical energy is an average of about $28 \%$. The energy stored by the battery is $4.1 \mathrm{kWh}$. There is a difference between the energy generated and stored in the battery. This is because there is energy loss in the SCC. In this observation, SCC has an average efficiency of $99 \%$.

Figure 6 shows the voltage and current performance from the DC side, which is from the solar panel generation and battery storage. The solar panel voltage and current (PV) follow the solar insolation graph, with the average value during PSH (09.45 to 14.15$)$ is $51.5 \mathrm{~V}$, and the current is $2.8 \mathrm{~A}$. This is because the solar panels are connected in series 3 . Under 24-hour loading, the battery is always in a state of charge at least about 93\%. This can be seen from the achieved minimum battery voltage, which is $12.2 \mathrm{~V}$. Meanwhile, the battery in full condition is $12.9 \mathrm{~V}$. This means that the battery has excess capacity compared to the use of an electric load for 24 hours. On the other hand, the charging current to the battery also follows the contours of the solar insolation graph, with the average value during PSH is $10.2 \mathrm{~A}$. It refers to the weather data accessed on the 
Accuweather page (source: https://www.accuweather.com/id/id/medokan-ayu/1685675/julyweather/1685675) on 15 July 2021. It was showing clear cloudy weather with an ambient temperature of $34{ }^{\circ} \mathrm{C}$. From the AC side, the inverter showed good performance during the test with an average voltage of $226 \mathrm{~V}$ and never less than $225 \mathrm{~V}$. The inverter used is a modified sine wave type with a capacity of $500 \mathrm{~W}$. With variations in input loading of $5.5 \mathrm{~W}$ and $34 \mathrm{~W}$, the inverter does not show a decrease in performance. The loading of 5.5 W was conducted for 12 hours from 18:00 to 06.00, whereas the loading of $34 \mathrm{~W}$ was conducted for 12 hours from 06.00 to 18.00 . The energy produced is used an average of $411 \mathrm{kWh}$ per day.

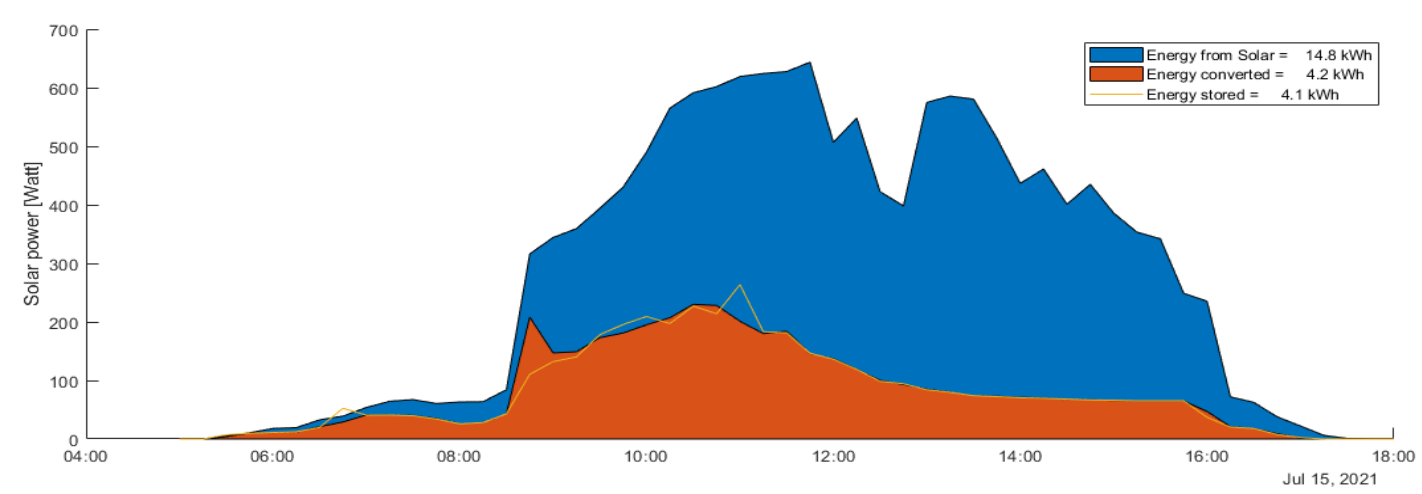

Figure 5. Solar power compared to PV module output occurred in the location
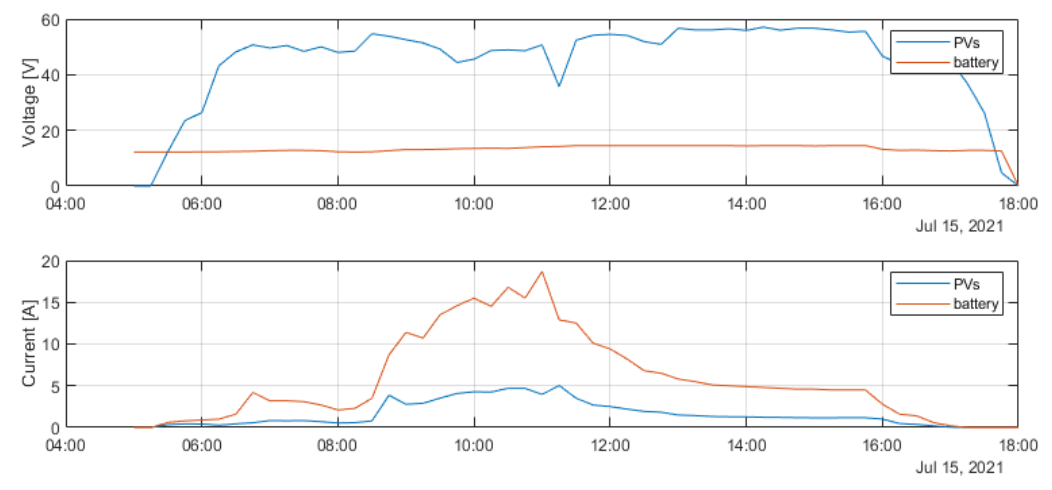

Figure 6. PVs and battery electricity measurement occurred in the location

\section{CONCLUSION}

The SHS design proposed in this study can be applied to housing with various electrical device loads. The calculation of the potential of solar energy can be done using primary data, which is by measuring the solar power directly in the field. It can also be done using the secondary data obtained from RETScreen. The calculation of electricity demand per day can be done based on the capacity of the electrical load and the electrical power. The correct calculation of potential and electricity demand, it will produce an SHS design that is feasible to be applied in real conditions. Performance analysis also determines the reliability of SHS in the housing sector. The design and construction of the SHS in this study show good performance in terms of energy harvesting and energy use. The battery is never empty, even though the weather conditions are cloudy or even rainy. Electrical energy harvested form the SHS is always available in good quality for 24 hours everyday.

\section{ACKNOWLEDGEMENTS}

We are grateful to the Faculty of Advanced Technology and Multidiscipline, Universitas Airlangga, also Programme of Matching Fund by Ministry of Education and Culture of Republic Indonesia for providing funds for this internal research grant in 2021. 


\section{REFERENCES}

[1] B. Parida, S. Iniyan, and R. Goic, "A review of solar photovoltaic technologies," Renewable and Sustainable Energy Reviews, vol. 15, no. 3, pp. 1625-1636, 2011, doi: 10.1016/j.rser.2010.11.032.

[2] J. Khan and M. H. Arsalan, "Solar power technologies for sustainable electricity generation-A review," Renewable and Sustainable Energy Reviews, vol. 55, pp. 414-425, 2016, doi: 10.1016/j.rser.2015.10.135.

[3] M. M. Hasan and M. F. Khan, "A comparative study on installation of solar PV system for grid and non grid rural areas of Bangladesh," 2nd International Conference on the Developments in Renewable Energy Technology (ICDRET 2012), 2012, pp. 15 .

[4] J. Kumar, N. R. Parhyar, M. K. Panjwani, and D. Khan, "Design and performance analysis of PV grid-tied system with energy storage system," International Journal of Electrical and Computer Engineering, vol. 11, no. 2, pp. 1077-1085, 2021, doi: 10.11591/ijece.v11i2.pp1077-1085.

[5] A. Loubna, T. Riad, and M. Salima, "Standalone photovoltaic array fed induction motor driven water pumping system," International Journal of Electrical and Computer Engineering, vol. 10, no. 5, pp. 4534-4542, 2020, doi: 10.11591/ijece.v10i5.pp4534-4542.

[6] K. Kaliappan, M. Sankar, B. Karthikeyan, B. Vineeth, and V. C. Raju, "Analysis of solar energy technology in leading countries," International Journal of Power Electronics and Drive Systems, vol. 10, no. 4, p. 1995, 2019, doi: 10.11591/ijpeds.v10.i4.pp19952004.

[7] T. Hasan, M. F. Nayan, M. A. Iqbal and M. Islam, "Smart Solar Home System with Safety Device Low Voltage Alert," 2012 UKSim 14th International Conference on Computer Modelling and Simulation, 2012, pp. 201-204, doi: 10.1109/UKSim.2012.36.

[8] M. R. Khan, S. A. Chowdhury and M. F. Khan, "Reduced battery sizing in a Solar Home System with respect to the night load and solar panel size," 2nd International Conference on the Developments in Renewable Energy Technology (ICDRET 2012), 2012, pp. $1-4$.

[9] A. D. Asham, M. Hanaa, B. Alyoubi, A. M. Badawood and I. Alharbi, "A simple integrated smart green home design," 2017 Intelligent Systems Conference (IntelliSys), 2017, pp. 194-197, doi: 10.1109/IntelliSys.2017.8324290.

[10] M. K. Singh, S. Sajwan and N. S. Pal, "Solar assisted advance smart home automation," 2017 International Conference on Information, Communication, Instrumentation and Control (ICICIC), 2017, pp. 1-6, doi: 10.1109/ICOMICON.2017.8279092.

[11] S. Ashraf, A. Raza, Z. Aslam, H. Naeem, and T. Ahmed, "Underwater Resurrection Routing Synergy using Astucious Energy Pods," Journal of Robotics and Control (JRC), vol. 1, no. 5, pp. 173-184, 2020, doi: 10.18196/jrc.1535.

[12] S. Pant and R. P. Saini, "Solar Water Pumping System Modelling and Analysis using MATLAB/Simulink," 2020 IEEE Students Conference on Engineering \& Systems (SCES), 2020, pp. 1-6, doi: 10.1109/SCES50439.2020.9236716.

[13] R. K. Megalingam and V. V. Gedela, "Solar powered automated water pumping system for eco-friendly irrigation," 2017 International Conference on Inventive Computing and Informatics (ICICI), 2017, pp. 623-626, doi: 10.1109/ICICI.2017.8365208.

[14] M. Nassereddine, K. Ali, and C. Nohra, "Photovoltaic solar farm: Earthing system design for cost reduction and system compliance," International Journal of Electrical \& Computer Engineering, vol. 10, no. 3, pp. 2884-2893, 2020, doi: 10.11591/ijece.v10i3.pp2884-2893.

[15] M. Suresh and J. George, "Study of the lighting sources of street vendors in Kerala and their willingness to switch to solar lanterns," 2015 IEEE International Conference on Computational Intelligence and Computing Research (ICCIC), 2015, pp. 1-4, doi: 10.1109/ICCIC.2015.7435791.

[16] B. Cheng et al., "Automated Extraction of Street Lights From JL1-3B Nighttime Light Data and Assessment of Their Solar Energy Potential," in IEEE Journal of Selected Topics in Applied Earth Observations and Remote Sensing, vol. 13, pp. 675-684, 2020, doi: 10.1109/JSTARS.2020.2971266.

[17] S. M. Qaisar, W. M. Alzahrani, F. M. Almojalid and N. S. Hammad, "A Vehicle Movement Based Self-Organized Solar Powered Street Lighting," 2019 IEEE 4th International Conference on Signal and Image Processing (ICSIP), 2019, pp. 445-448, doi: 10.1109/SIPROCESS.2019.8868384.

[18] M. Alahmad, M. A. Chaaban and L. Chaar, "A novel Photovoltaic/Battery Structure for Solar Electrical Vehicles [PVBS for SEV]," 2011 IEEE Vehicle Power and Propulsion Conference, 2011, pp. 1-4, doi: 10.1109/VPPC.2011.6043145.

[19] B. I. Yassine and A. Boumediene, "Renewable energies evaluation and linking to smart grid," International Journal of Power Electronics and Drive Systems, vol. 11, no. 1, pp. 107-118, 2020, doi: 10.11591/ijpeds.v11.i1.pp107-118.

[20] S. Z. Islam, M. L. Othman, N. Mariun, H. Hizam, and N. Ayuni, "Feasibility analysis of standalone pv powered battery using SEN for smart grid," International Journal of Power Electronics and Drive Systems, vol. 11, no. 2, pp. 667-676, 2020, doi: 10.11591/ijpeds.v11.i2.pp667-676.

[21] P. Megantoro, F. Danang Wijaya and E. Firmansyah, "Design of solar water pumping system in urban residential building: (Case study: Yogyakarta, Indonesia)," 2017 International Conference on Control, Electronics, Renewable Energy and Communications (ICCREC), 2017, pp. 122-126, doi: 10.1109/ICCEREC.2017.8226696.

[22] R. A. Diantari and I. Pujotomo, "Calculation of electrical energy with solar power plant design," 2016 International Seminar on Intelligent Technology and Its Applications (ISITIA), 2016, pp. 443-446, doi: 10.1109/ISITIA.2016.7828701.

[23] C. Khin, P. Buasri, R. Chatthawom and A. Siritaratiwat, "Estimation of Solar Radiation and Optimal Tilt Angles of Solar Photovoltaic for Khon Kaen University," 2018 International Electrical Engineering Congress (iEECON), 2018, pp. 1-4, doi: 10.1109/IEECON.2018.8712118.

[24] M. Paluch, R. Fasuga and T. Bilek, "Tool for Calculation of Solar Radiation and Solar Systems Design," 2011 UKSim 5th European Symposium on Computer Modeling and Simulation, 2011, pp. 305-310, doi: 10.1109/EMS.2011.66.

[25] M. A. Bukvina, M. A. Falynsky, R. A. Eshenko and M. A. Popov, "Development of Software for Calculating the Level of Insolation at a Point with Specified Coordinates in Order to Optimize the Construction Site of Solar Power Plants," 2020 International MultiConference on Industrial Engineering and Modern Technologies (FarEastCon), 2020, pp. 1-5, doi: 10.1109/FarEastCon50210.2020.9271450.

[26] G. L. Morrison and Sudjito, "Solar radiation data for indonesia," Solar Energy, vol. 49, no. 1, pp. 65-76, Jul. 1992, doi: 10.1016/0038-092X(92)90128-W

[27] P. Megantoro, I. E. Prabowo, and M. A. Shomad, "Development of Maximum Power Point Tracking Solar Charge Controller for 120 Volt Battery System at Pandansimo Hybrid Power Plant," Journal of Physics: Conference Series, vol. 1471, no. 1, p. 012047, 2020, doi: 10.1088/1742-6596/1471/1/012047

[28] P. Megantoro, F. Danang Wijaya and E. Firmansyah, "Analyze and optimization of genetic algorithm implemented on maximum power point tracking technique for PV system," 2017 International Seminar on Application for Technology of Information and Communication (iSemantic), 2017, pp. 79-84, doi: 10.1109/ISEMANTIC.2017.8251847.

[29] P. Megantoro, Y. D. Nugroho, F. Anggara, Suhono and E. Y. Rusadi, "Simulation and Characterization of Genetic Algorithm 
Implemented on MPPT for PV System under Partial Shading Condition," 2018 3rd International Conference on Information Technology, Information System and Electrical Engineering (ICITISEE), 2018, pp. 74-78, doi: 10.1109/ICITISEE.2018.8721031.

[30] P. Megantoro, Y. D. Nugroho, F. Anggara, A. Pakha and B. A. Pramudita, "The Implementation of Genetic Algorithm to MPPT Technique in a DC/DC Buck Converter under Partial Shading Condition," 2018 3rd International Conference on Information Technology, Information System and Electrical Engineering (ICITISEE), 2018, pp. 308-312, doi: 10.1109/ICITISEE.2018.8721005.

\section{BIOGRAPHIES OF AUTHORS}

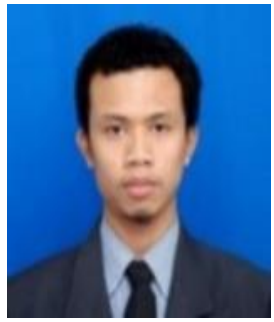

Prisma Megantoro (iD IS SC P has been a lecturer in Electrical Engineering, School of Advanced Technology, and Multidiscipline, Universitas Airlangga since 2020. He received a bachelor's degree and master's degree from Universitas Gadjah Mada, Yogyakarta, Indonesia in 2014 and 2018. His current research is focused on solar photovoltaic technology, embedded system, and the internet of things. The author can be contacted at email: prisma.megantoro@stmm.unair.ac.id.

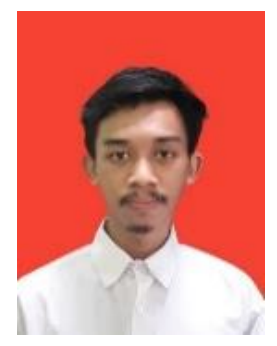

Hafidz Faqih Aldi Kusuma (D) 81 SC P was born in Surabaya, Indonesia in 2000. After graduating from high school he continued his studies at the Institut Teknologi Sepuluh Nopember, majoring in Information and Applied Computer Education in 2018 with a study period of one year. Then continued his studies in electrical engineering at Universitas Airlangga in 2020. Now he is active in the robotics community of the flying robot division, and he is also active in the instrumentation research group. The author can be contacted at email: hafidz.faqih.aldi-2020@stmm.unair.ac.id.

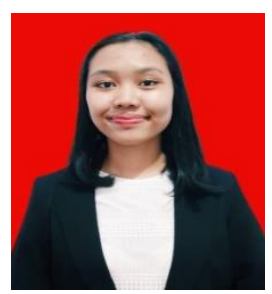

Sinta Adisti Reina (D) 8d SC P was born in Mojokerto, East Java, Indonesia in 2000. She received a bachelor's degree in Biomedical Engineering in 2021 from the Universitas Airlangga. She is an intern Airlangga Publication Center team at the Faculty of Advanced Technology and Multidiscipline, Universitas Airlangga, Indonesia. The author can be contacted at email: sinta.adisti.reina-2017@fst.unair.ac.id.

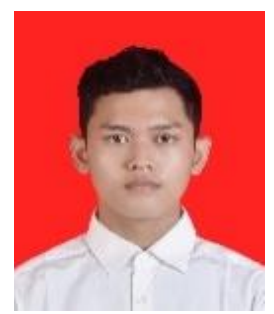

Abdul Abror (iD 8f SC P was born on 10 October 2002. After graduating from high school, he continued his study at Universitas Airlangga, majoring in electrical engineering in 2020. Now he is active in the robotics community of the soccer robot division, Mikrotik networking community, cisco networking community, and also he is active in the instrumentation research group. The author can be contacted at email: abdul.abror-2020@ stmm.unair.ac.id.

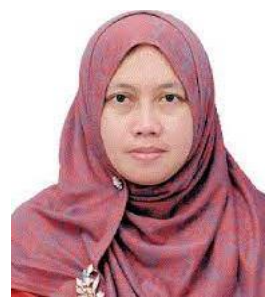

Lilik J. Awalin (D) 8d SC P was born in East Java, Indonesia, in 1977. She received the B.Eng. degree in electrical engineering in 1999 from the University of Widya Gama, an M.Eng. degree in 2004 from the Institut Teknologi Sepuluh Nopember, Indonesia, and a Ph.D. degree in 2014 from the University of Malaya. she was a Senior Lecturer in International College of University Kuala Lumpur, Malaysia from 2015 to 2020. Currently, she is head of the section at Universitas Airlangga, Indonesia. The author can be contacted at email: lilik.j.a@stmm.unair.ac.id.

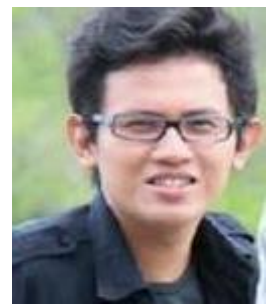

Yusrizal Afif (DD Bd SC P was born in Surabaya, East Java, Indonesia in 1992. He received Bachelor's and Engineering degree in Electrical Engineering from Institut Teknologi Sepuluh Nopember, Surabaya, Indonesia, in 2015. From 2015 to 2017 he worked as a project engineer at Krakatau Daya Listrik Co., Indonesia. He received a Master Engineering degree in Electrical Engineering from Institut Teknologi Sepuluh Nopember in 2019. He joined Universitas Airlangga in 2020 as a lecturer. His research concentrates mainly on high voltage technology, apparatus characteristics, discharge phenomena, and renewable energy. The author can be contacted at email: yusrizal@stmm.unair.ac.id. 